\title{
Surfaces
}

\section{MODERNITY AND THE VERNACULAR}

\section{Bennet Schaber}

Volume 1, 1991

URI : https://id.erudit.org/iderudit/1065260ar

DOI : https://doi.org/10.7202/1065260ar

Aller au sommaire du numéro

Éditeur(s)

Les Presses de l’Université de Montréal

\section{ISSN}

1188-2492 (imprimé)

1200-5320 (numérique)

Découvrir la revue

\section{Citer cet article}

Schaber, B. (1991). MODERNITY AND THE VERNACULAR. Surfaces, 1. https://doi.org/10.7202/1065260ar
Résumé de l'article

Le vernaculaire dans la littérature médiévale, le jazz, et le rock and roll, comme pratique d'avant-garde. La recherche sans règle préexistante d'une socialité sans règle préexistante. Contraste entre l'expérimentation moderniste (qui est téléologique et s'inscrit dans un projet) et la rencontre du vernaculaire avec le hasard pur. Les poétiques sociales du vernaculaire comme façon de repenser la relation entre la littérature et la société.
Ce document est protégé par la loi sur le droit d'auteur. L'utilisation des services d’Érudit (y compris la reproduction) est assujettie à sa politique d'utilisation que vous pouvez consulter en ligne.

https://apropos.erudit.org/fr/usagers/politique-dutilisation/ 
MODERNITY AND THE VERNACULAR

Bennet Schaber[*]

\begin{abstract}
The vernacular in medieval literature, jazz, and rock and roll, as an avantgarde practice, a search for a sociality in the absence of pre-existing rules. Contrast between modernist experimentation (which is teleological and project-oriented) and the vernacular encounter with sheer chance. The social poetics of the vernacular as a way of rethinking the relation between literature and society.
\end{abstract}

\title{
RÉSUMÉ
}

Le vernaculaire dans la littérature médiévale, le jazz, et le rock and roll, comme pratique d'avant-garde. La recherche sans règle préexistante d'une socialité sans règle préexistante. Contraste entre l'expérimentation moderniste (qui est téléologique et s'inscrit dans un projet) et la rencontre du vernaculaire avec le hasard pur. Les poétiques sociales du vernaculaire comme façon de repenser la relation entre la littérature et la société. 
something was Jes Grewing just like the 1890s flare-up... There are no isolated cases in this thing. It knows no class no race no consciousness. It is self-propagating and you can never tell when it will hit... A mighty influence, Jes Grew infects all that it touches... Actually Jes Grew was an anti-plague. Some plagues caused the body to waste away; Jes Grew enlivened the host."

\author{
--Ishmael Reed, Mumbo Jumbo
}

"Sometimes I play things I've never heard before."

--Thelonious Monk

"Perkin's Wiggle" was recorded at Sun Studios in Memphis in 1956 by Carl Perkins, one of the inventors of rock and roll and the man who gave us "Blue Suede Shoes"[1] . A kind of /pp 5-6/ amalgam of hill-billy guitar and a swing beat, beginning on $\mathrm{F}$ (tonic), jumping to $\mathrm{A}$ and ascending chromatically (B flat, B) until it reaches $C$ (dominant), the song's first verse goes like this:

Well, down, in dixieland,

A red-hot rhythm we don't understand;

Everybody does it but they never stop--

Playin' the Perkin's Wiggle with a dixie bop.

I've transcribed the lyrics from a recording, so I cannot vouch for their absolute accuracy. The initial "Well" may in fact be a "Way" (and the "Playin'" of line four is later changed to "Doin'"). In either case, whether "Well" or "Way," the kind of guttural 'uh huh' of the first word gives to the song the sense that it was sung in response to a question: "Just what is it that you're playing, Carl?" "Well," Carl responds, and the song follows. So what exactly is the Perkin's Wiggle? The song tells us that it is something "Everybody does," but also that it is something "we don't understand." Besides this characterization, however, we have precious little information about the Perkin's Wiggle. Is it a dance? If so, we know what the music sounds like, but not what the dance looks like; that is, just exactly what kind of wiggle it might be. In fact, I've yet to meet anyone who can explain definitively, or even describe, the Perkin's Wiggle. Many people can do the twist, the dance 
popularized and explicitly marketed by Chubby Checker. People can even do Prince's Batdance, because the song and its steps originate in a

/pp 6-7/

video image (even as these images originate in Tim Burton's film, Batman). But the Perkin's Wiggle is something of a mystery, a secret even. I listen to this song and can invent a wiggle; indeed, I can experiment with all sorts of wiggles.

This wiggle and its secret seem to me to be pervasive across the near entirety of Perkins's oeuvre. One need only look hard at the title of his most famous song, "Blue Suede Shoes," to see the letters literally wiggle. "Suede" is a partial anagram, borrowing its letters from "Blue" and "Shoes;" and the dancing letters would seem to support a homonymic slide from "suede" to 'sway(ed)'. Indeed, one gets the sense that the song in no way derives from any real referent, any actual pair of footwear. "Shoes" simply rhymes with 'blues', which together produce the anagram-adjective that connects them, thereby magically creating the referent, not from which the song derives, but which it literally calls into being, along with all of its apparent meaninglessness. "Blue Sude Shoes," then, becomes a metaphor for nothing that exists in the world--yet. It names a music and a performance that as yet have no name (called variously by Perkins: "go cat," "bop," "boogie," "rock and ride," "rhythm bound," but never once rock and roll). It is quite literally (and paradoxically, because it is a metaphor) "a red-hot rhythm we don't understand."

Of course there is no sense in arguing that blue suede shoes never existed, that they were not in fact a style, or had no real, cultural resonances.

However, my claim is simply that Perkins's song de-realizes the shoes it no longer sings about so much as sings (into existence). That is, I am struck by the song as being in excess of what it is nominally about (and hence I am taking 'to sing' as a transitive verb). About Perkins's shoes one might say what Heidegger, in "The Origin of the Work of Art," did about Van Gogh's: "A pair of [blue suede] shoes and nothing more. And yet--." It may not be all that fanciful, then, to take note of the play of letters across the words "blue suede shoes," the metathesis to which they seemingly submit themselves. For even if Perkins has a real pair of shoes in mind, it is at the moment these shoes begin to sing

/pp 7-8/

that something happens that we don't quite understand. Perkins's shoes take on a new power, announce themselves as no longer just shoes. Rather than standing in for an assertion of cultural identity, what stands in and upon these shoes constitutes itself as the terpsichorean fantasy of culture as 
radically unfinished: a world, a wiggle and a pair of shoes in search of their choreography.

Perkins gives a musical account of his origins in "Everybody's Trying to Be My Baby": "Well they took some honey, from a tree;/ Dressed it up and they called it me." Now, this "honey" remains problematical throughout Perkins's compositions; it is as capable of designating the singer or addresser of the songs as the listener or addressee. For example, in "Honey Don't": "How come you say you will when you won't,/ Tell me you do, baby, when you don't;/ Let me know, honey, how you feel;/ Tell the truth now is love real;/ But uh, uh, honey don't." The account of his own origin is at one and the same time the account of the origin of his listener. The honey-baby, then, forms the lexical and seemingly organic double origin of both performer and audience. There is a relation between the birth of the composer, the honeybaby, and the birth of his interlocutor, also called honey and who is "trying to be [his] baby." Song becomes enlivening and engendering--it gives birth to both the performer and the one for whom he performs in a moment of absolute and metamorphic creation.

The origin of song is phrased by Perkins in no less ambiguous terms. For example, in "Bopping the Blues": "All my friends are bopping the blues, it must be going round." And later: "The doctor told me, Carl you don't need no pill;/ Just a handful of nickels in the jukebox will cure your ill." "Going round," bopping the blues is compared to a sickness or a disease, to catching a 'bug': "That jitter-bug caught me, man I don't feel no pain;/ I love you, baby, but I'll never be the same." Like his own origin, double and other than itself because it will include the other to and for whom he sings, the origin of song is itself "never the same." And the 'never the same' would seem to go as well for that "red-hot rhythm we don't understand," Perkin's Wiggle. Literally "red-hot," this wiggle

/pp 8-9/

catches fire, spontaneously combusts into a species of "Jes Grew," the musical and vernacular anti-plague described by Ishmael Reed (or, for that matter, Boccaccio, who used the metaphorics of conflagration to describe both the Florentine plague and his own vernacular composition).[2] /pp 9-10/

Like a fire-brand, then, song burns through the social tissue of the musical score. But the fire refuses to quench itself, even under the sign of its own negativity. It keeps one eye open and its honey-tongue of flame poised toward childbirth and toward the kids. Not yet squashed beneath the representational weight of adolescent, high-school life and sex at the drivein (the fate that awaited the songs of Chuck Berrry, Bill Haley, even Buddy 
Holly), the "children" of Perkins's songs want nothing but to "bop 'til they pop."

There was an old woman who lived in a shoe,

She had so many many children she didn't know what to do.

They were doing alright 'til she took 'em to town;

The kids started pickin' 'em up and puttin' 'em down.

All your children want to rock, mama;

All your children want to roll.

Want to roll, want to rock, want to bop 'til they pop,

All your children want to rock. ("All Mama's Children")

'Pop' songs all, but hardly derivable (lexically, semanticaly, culturally) from anything popular, their popping is both copulative and parturitional at the same time. 'Pop' refuses the 'facts of life' which it does not understand.[3] / pp 10-11/

The inscription of "pop" in "All Mama's Children," the anasemia to which it is submitted, points to the central and enduring question posed by Perkins's songs: how to trace the paternity--the pop or papa--of so-called popular music? In short, popular song argues for its own problematical origin from within a decay of patriarchy and patrilineal descent. It derives the place of 'pop' from within mama's house, the old woman's shoe, so that 'pop' bespeaks not the origin but the conclusion toward which song falteringly strives. The 'pop' song, therefore, as phrased by Perkins, as un-fathered music, is not in any strict sense popular. It turns what would no doubt strike a Freudian as an infantile theory of sexuality into a radical and mysterious theory of social genesis. It depicts its origins and desires in terms that are at turns simple and incomprehensible. "We want to live in a blue suede shoe," ends the second verse of "All Mama's Children," so that Perkins's musical signature, the name of his only real 'hit', comes to name a moment of social striving, a reconfiguration and transformation of domestic space.

I want to understand the Perkin's Wiggle, to fathom its secret in some way that might continue, nevertheless, to maintain it as a secret. In short, I want 
to understand something that, in order to understand it, "we don't understand." Specifically, I want to (not) /pp 11-12/ understand this song (and the alleged dance to which it refers and which bears the name of its composer/author) as written in a language that, in some essential respect, does not undestand itself. I will call this language (both musical and linguistic) the vernacular. And I also want to (again, not) understand this song as it performs itself in 1956, as it announces its modernity at the beginning of rock and roll. This modernity declares itself in a strange enough way that perhaps it ought to be called postmodernity. Perhaps, then, this essay, as it worries over questions about postmodernity and the vernacular, will have been the wiggle it is after. Or at least some version of it.

\section{Chaucer Street}

In order to reach (but not to solve) the mystery of the Perkin's Wiggle, I will want to take something of an extended detour and assert, in some substantial way, that there is a relation between what we call, or intuitively judge as, postmodernity, and that something I have already called the vernacular. I would, however, like to rephrase this as the question of modernity tout court. What is modernity?--a question one can put, I think, even to an artefact arrived out of the past. For example, what constitutes the modernity of a medieval text? Which I do not think means exactly the same thing as posing the question of its contemporaneity with its own age or with other texts with which it would seem to share, at least, a certain chronological positioning or identity. Hence my phrasing of the postmodern, if it is temporal in fact, is not by virtue of that chronological. A problem, no doubt, for those of us who have been enjoined to "always historicize."[4] This injunction seems to me to be vague at best, pernicious at worst. /pp 12-13/

In order to answer the question--what constitutes modernity?--, I would like to follow an argument of J.-F. Lyotard and think modernity in terms of the experiment.[5] What do I mean by this term, experiment? Before answering, let me say first that I am /pp 13-14/ using the word 'modernity' in order not to have to say 'modernism', which names a project, both aesthetic and political. And the same goes for my choice of 'postmodernity' rather than 'postmodernism'. I want to avoid, as much as possible, the various kinds of confusions--definitional, partisan, etc.--that come along with the project of turning words into substantives of the 'ism' sort. I do not know yet, however, if this is even possible. But I do know that I want to distance my use of words like modernity or postmodernity from any sense that they designate movements or schools, that is, something that might be organized, even after the fact, by a derivation from so-called social or historical facts. In truth, I will want to reverse this and claim that the experiments about which I will speak do nothing less than establish the fact of their own sociality. They are, in the strictest sense, experiments, rather than innovations 
recognizable as such by the simple modifications they make in established, long-standing traditions.[6]

So let me return to my question--what constitutes modernity, or what constitutes the modernity of something? And is this something of the nature of an experiment? Or, to use a word I like, since it implies taking chances, an adventure? Per aventura, a Provencal lyric might say, done by chance.[7] /pp 14-15/ I need the chance aspect to go along with my experiment, because I do not mean an experiment of any type. No doubt Joyce writes what might be called 'experimental novels', but he never writes a novel by chance. His entire oeuvre, in a way, is of a piece, including Finnegan's Wake, which he directed to the University in order to "keep the professors busy for centuries."[8] Now Joyce was always interested in the university, in education and pedagogy, in paedeia--the education of young men. And this is true from Dubliners on. Is there some relation, he asks, between, for example, paedeia and /pp 15-16/ pedophilia? Between or among education, perversion, violence, etc.?[9] And he fashions his response as an experiment for and within a pedagogical context. I know that many Joyceans refer to all this as "the industry"; but it is no industry at all, it's the university, and the industrial discourse seems to me to obscure the point.

Joyce, then, who is as modernist as they get, does not strike me as particularly modern; we might even call him classical, insofar as classicism defines itself as capable of elaborating and acting upon a theory of taste and sensibility and finds an audience for itself that is commensurate with that theory as it is acted out.[10] In Joyce we find the audience with a taste for Racine or Corneille simply transferred from the theater to the university. So the whole thing is supported, from beginning to end, by a kind of pedagogy: from the S-M-P of Stephen, Molly, Poldy, which is the subject-middlepredicate of the syllogism so dear to Scholastic demonstration, to all the maps and tables spilled into the lap of Stuart Gilbert.[11]

Racine does not write a tragedie by chance; Joyce writes an experimental novel and covers his bets. He knows what he's doing. If that in no way diminishes his genius, it does diminish the risks involved. And the experiment I want to call modernity simply cannot do this. By way of illuminating this, I'd like to examine a short sequence from a film, Jim Jarmusch's 1989 Mystery Train, because it introduces one of those adventures, those chance occurrences, which both surprise and convince. I hope that this will help me explain something of what I mean by experiment, chance and adventure.

/pp 16-17/

The sequence is comprised of three scenes: the first in a Memphis train station, the second a street, the third Sun Studios. A young Japanese couple 
sits in the station, the man gazing around distractedly, the woman reading a travel guide. "Sun Studios, 706 Union Avenue," she says, reading from the guide. "Carl Perkins, Howlin' Wolf, Jerry Lee Lewis, Roy Orbison," the young man responds as if being drawn out of a daydream. "They all recorded there; not just Elvis." And after a long breath, "Carl Perkins," he intones in a Japanese accent. Cut to the same couple walking down a street of fairly drab and uniform bungalows. "Chaucer Street," says the woman, reading the street sign. Cut to Sun Studios and a rather tawdry guided tour. "It was right here in this room that Mr. Sam Phillips recorded the likes of Howlin' Wolf, Rufus Thomas, James Cotton, Johnny Cash, Carl Perkins, Roy Orbison, Jerry Lee Lewis and of course, Elvis Presley," says the guide, repeating with something of a lilting twang the litany of names we have just before heard chanted in Japanese accents.

Perhaps this sequence of shots will not astonish you in the way it astonishes me. And this is because I find in this little sequence a kind of confirmation of something I've been working on and writing about for some time now. Not because I think that there is some strict relation between Chaucer (the street along which the young Japanese couple strolls bears his name, and the incidental music to this section of the film is called by its composer, John Lurie of The Lounge Lizards fame, 'Chaucer Street') and what has come to be known as the 'Memphis sound', but because those figures of early rock and roll, whose names are listed first by the young couple and then again by the tour guide at Sun Studios, and Chaucer, would seem to share a certain fundamental situation. I would place this situation under the heading of what I call the vernacular. I would postulate that there is some fundamental relation between the 'fathers' (or 'pops') of rock and roll and the 'father' of English poetry; and that relation is the vernacular, the 'mother tongue'. Like Chaucer, the early rockers make the mother tongue sing as never before. And it is this 'never before' that sets their /pp 17-18/ work apart and makes it so difficult to produce a contemporary judgment of it, at least a judgment that can produce its own reasons or the criteria by which it judges (a situation Dick Clark attempted to rectify by having songs judged on a ratings scale of one to ten).

"That's it, that's what I like, that's what I'm looking for, that's more like it, you all keep playing," his first record producer, Sam Phillips, is said to have responded to Elvis. And the phone lines light up--is the singer black? is he white?--so that Elvis's first tune is played a dozen times on its first night of release. People like it, even if they can't quite say what it is or why. And they come together, around radios and phones; they feel compelled to respond to what they hear in some way. No one could have forseen this, not the performer, the producer or the disc jockey. It all just happens, seemingly by chance.

No one who hears this music on its first night knows where it comes from or what it means. They know they like it, they feel the pleasure it produces, but 
this pleasure is not yet hemmed in by the series of discourses which usually elaborate cultural pleasures and make them safe by designating their origins, destinations and meaning. And it is this pleasure lacking its own meaning that elicits the direct response--as opposed to the direct consumption--of its listeners. What I will designate as the vernacular will be just this kind of cultural production that ranges far ahead of its own possible meaning, and precisely because it lacks its own meaning. That is what I want to examine as the cultural experiment specific to modernity; the experiment as a work poised around its own lack-of-meaning. And beyond this, that this lack--which gives to the work its excessive quality--is the very condition of the work's production and reception. It cannot be derived from any pre-existing discourse (even if it makes use of certain elements of it) nor submitted to a theoretical or historical discourse dependent upon the possibility of such a derivation, without falsifying it in some important way. This is why I will be forced to say that occasions like this come about by chance or ex nihilo. And I think Jarmusch has an intuitive sense of this, that it is as true for Elvis as for Chaucer (and--I have not forgotten him--Carl Perkins).

/pp 18-19/

\section{II. "Now they'll have to change their tune."}

During Day 1 of the conversations between Jean-Francois Lyotard (JFL) and Jean-Loup Thebaud (JLT) published as Just Gaming, the dialogue turns to the question of "pop music."[12] "... pop music is not modern," JLT asserts, "it is as classical as can be, because it is addressed to a certain audience, and it is just not true that it is not known whom it is addressed to. It is still a question of pleasing and affecting." This assertion, both bald and bold, elicits a question from JFL: "How are you taking the term 'pop music'?" To which JLT responds: "The term says it well: 'popular music', which means that its support and its addressee are indeed the people." JFL, it seems, cannot accept this definition, and registers his unhappiness with it in immediate and certain terms: "No, it means popular in the sense that in modernity there is no longer a people."

The cards, then, are on the table. And what is at stake is, if not a definition, then at least a phrasing of the question of modernity. And it is made clear, in a note appended to the text a few pages later, that this phrasing is also that of the question of the postmodern.[13] How to understand 'pop music' for a modernity in

/pp 19-20/ which "there is no longer a people"? How is one to make a distinction between what is 'pop' and what is 'popular'? Or, to put it another way, how might 'pop music' phrase the question of its own modernity? 
I would like to ponder these questions, with and against JFL and JLT, by listening to four pieces of music, all of them 'pop' although not necessarily 'popular': 1. "Pannonica," composed and performed by Thelonious Monk, 2. "Black and Tan Fantasy," composed by Duke Ellington and performed by Monk, 3. "'round Midnight," composed by Monk and performed by Miles Davis and Michel Legrand, and 4. "They All Laughed," composed by George and Ira Gershwin and performed by Louis Armstrong and Ella Fitzgerald. All of them were recorded in the mid-1950's.[14] What I want to listen for in these works is something they might have to 'say' about their own status as modern and as pop and/or popular. I want to listen for their particular phrases (musical, narrative, semantic) as a phrasing (and also an enacting) of what the conversation between JFL and JLT can only approach by way of commentary.

Let me begin with the last song first, because it has lyrics

/pp 20-21/

and would seem to be the most clearly 'pop' of the four songs.[15] "They All Laughed" is, as we say, not a classic but a standard. It allows the accomplished jazz vocalist to 'swing' over and against his or her oppositely gendered counterpart. Hence the twin co-ordinates of the tune: it phrases a modern, heterosexual relationship in terms of its own modernity. Two stories are being told here: the first in which modernity names itself as a procession of inventions or innovations for which the world was not quite prepared, the second in which a couple's liaison, its "wanting," is presented as the gendered, desiring correlative of the first. And there's a third story as well, made wholly from Armstrong's improvisations, when he changes "who has the last laugh now" to "this is the last laugh now." That is, he changes the song's referential encoding so that the song itself becomes a last laugh at and within modernity. In becoming self-referential, the song becomes itself the change of tune /pp 21-22/ it otherwise prescribes. That is, "wanting," the sexual relation the song performs, becomes the condition under which a description of modernity becomes a prescription for modernity. And that sexual relation, as such, does not exist apart from its performance as song. [16]

This strikes me as the fairly complicated and unmasterable fact of the song. It is what keeps the song from becoming only commentary; and it is what encodes and destines commentary to fall /pp 22-23/ short, so to speak, if it does not itself become a song in response to the first. In short, the song cannot be exhausted by any of the possible meanings it designates as modern, so that modernity, understood through the meanderings of two gendered voices (united through narrative but opposed through musical registers), can only finally be designated as that which consistently and 
invariably 'changes its tune'. 'Changing its tune' then, ceases to mean the rather laughable history of modern inventions and innovations, but beomes the two-part invention, the experiment, of the sexual relation as it sings itself. In this sense, "They All Laughed" phrases its modernity (or postmodernity) in concert with JFL's argument rather than JLT's. There is "no longer a people," a populus, to whom the song is addressed in particular, no stable "sound filtering system" to whose requirements the song absolutely conforms.

That filtering system is, however, in full operation in the Davis/LeGrand version of "'round Midnight." I included this performance because it is so clearly an interpretation of Monk's composition, an interpretation that takes the song's title seriously and anchors itself there. I think it has musical value: Davis sounds great and as distinctive as ever; LeGrand's arrangement is wonderfully textured. But the performance gives the appearance of being something of a soundtrack, to a film even. And just as any soundtrack 'originates', so to speak, in the image, so this performance attempts to originate itself in something beyond itself--a mood, a time, a place--urban and nocturnal. Hence the song's phrasing of modernity is close to JLT's. It announces itself as capable of producing its correlative image, and that image mediates the relation of the song to its public. The arrangement, then, is popular in a very strict sense.

It seems to me, then, that these two songs record, in their own ways, the terms of the debate between JFL and JLT a propos of modernity. The first frames itself as an experiment that undoes its own description of modernity through a prescriptive phrase directed toward its future and possible recomposition (grounded in the non-ground of sexual difference). The second takes modernity as already /pp 23-24/ given in advance and sets out to record it as music and commercial record album. It has the effect of turning Monk's composition into a classic, as JLT would say.

The two Monk songs give what may appear to be a kind of résumé of just this split. One is an original, a minor song from his oeuvre, the other a cover of an Ellington classic, one of his earliest. However, both performances are distinctively Monk, who sets his seal upon the Ellington tune, playing with harmonic dissonances, rhythmic modulations, so that he seems to be, at turns, ahead of or behind the melody, when he is not, seemingly, playing something completely different and in another key. We might say that he is, in a way, de-classifying Ellington's "fantasy" in favor of his own. I think "Pannonica" tells us something about what constitutes that fantasy.

The 1956 recording of "Pannonica," a solo composition for piano, is preceded by a short preamble, spoken by Monk and captured by the tape recorder. "I would like to play a little tune I just composed, not so long ago, 
entitled "Pannonica," says Monk. "It was named after this beautiful lady here. I think her father gave her that name, after a butterfly that he tried to catch. I don't think he caught the butterfly." Monk's "little tune" is very beautiful, halting in its complex phrasing of various tempos and tonally and harmonically as complex as it is elegant. At once a love song and a formal experiment, it is written for someone (Nica de Koenigswarter) and to or towards someone else (other musicians, no doubt, as well as to whatever audience Monk's experiment might have created). But the spoken introduction contains its own meanderings and subtleties as well as its own complex rhythms and phrasings; and these are not unrelated to the complexities of the tune and its status as what I will want to call a vernacular composition.

Monk's narrative concerns the naming of his composition; and as such, concerns itself also with an instance of social or familial naming. The name he gives to his tune, "Pannonica," is also the name a father has given to his daughter. The father names his /pp 24-25/daughter after a butterfly which, in Monk's account at least, he tried to catch, unsuccessfully. The proper name, therefore, marks and memorializes a certain failure, one that cannot be unrelated to the paternal desire instantiated in the daughter. If the daughter names, or bears the name of, the father's desire, she names it not as its fulfillment but as the very sign of its lack of fulfillment. Something of that desire could not be caught in its flight. Perhaps then, something of this same scenario is involved when the composer names his composition. The composer cannot quite grasp or catch his own work. He can play it, or play with it, just as the proper name, Pannonica, plays with the very conditions of playing itself: it anagramatizes the letters of the word 'piano' (which names as well the tune's dynamics, it is a 'quiet' piece) just as it resonates with the word 'harmonica' or harmonics (also a key element in its formal manipulations).

Monk's introduction, then, partakes of many of the same elements as the composition it introduces; it translates them by playing with and on the same trans-figurations (linguistic or musical). But the introduction does not say what the song means; instead, both intoduction and composition play around with a fundamental lack of meaning, with a tonal or semantic vanishing point of both narrative (as desire) and music (a certain deaf area within tonality, signalled by the quarter tone, which exists between two adjacent keys of the piano, which plays that tone only by sounding those keys simultaneously). Hence, one is often struck by the sense that there is something in Monk's playing that is simply not being heard, a sense Monk realizes by accentuating the pauses between musical (or narrative) phrases, through the jarring quality of his dissonances, the use of whole-tone scales and seemingly misplaced sevenths which signal themselves as nearly microtonal (despite the impossibility of producing pure micro-tones on a piano). 
I do not think that Monk's composition can be fully taken account of by, for example, a reference to the Bebop movement of the 40's and 50's, nor by reference to Monk's training at Julliard or /pp 25-26/ to major jazz influences, say, Fats Waller, Art Tatum or Duke Ellington, nor even by a biographical reference (which the narrative contains). Instead, the composition refers itself to and as a challenge to the desire insisting in the ear of the one who hears it. Can this other name his or her desire? And can she or he do it beyond the production of a counter-composition with its own, congruent, narrative and musical complexity? This, I think, is the challenge of Monk's "little tune," a minor work in a major key, so to speak. And this is also, I think, the challenge of vernacular production itself. Because once some other responds, in words or in music or in both, something new has begun to happen, and happen on a social scale (if we are willing to take the number two, or two persons, as the lower limit of sociality).

My argument, therefore, is that Monk's work ought not to be understood only in reference to an already constituted set of established social facts; that it cannot be derived from any of the possible (critical) discourses which might claim to deduce it from the (historical) discourses of music, class, race, ethnicity, etc. Nor can any of these discourses provide a set of stable criteria for its judgment or assessment. Not that these discourses did not or do not continue to exist for it, far from it. But each of them will or must take as its aim the naming of the meaning of Monk's work. And in setting forth to do just that, they inevitably lose sight of the butterfly that refuses to be caught where it is not. "I don't be around the corner, looking to see what's happening," Monk told an interviewer. "I'm not a policeman or a social worker."[17] In short, Monk's "little tune" establishes the fact of its own sociality and its own modernity precisely by fissuring the plenitude of modern meanings through the (failed) inscription of desire--as narrative and tonal disjunction. "They All Laughed" does something of the same thing, through the inscription of a gendered "wanting," and in a more explicit and no doubt more breathtaking way.

/pp 26-27/

There are, then, it seems to me, two competing determinations and definitions of modernity at play across the objects I am presenting for your inspection/audition. One in which modernity names the fact of cultural production as in situ, that is as classically contemporaneous with itself and its time. Another in which modernity names the experiment which consistently attempts to give birth to itself, that takes chances in its own adventure. The first definition would gloss the term 'pop' as a shorthand for a determined and determinable populace capable of embracing its own modernity as innovative classicism. The second would return us to Carl Perkins's formulation: 'pop' as the copulative and parturitional moment capable of undoing the popular and accepted representations of organic, 
aesthetic and social genesis. I have associated the latter with something I've been calling the vernacular; and now I must say why.

\section{III. "I don't know what it means" (no say de cuy)}

Introducing what he calls a "vernacular theory" of Afro-American literature, Houston Baker makes the following observation: "If desire and absence are driving conditions of blues performance, the amelioration of such conditions is implied by the onomatopoeic training of blues voice and instrument. Only a trained voice can sing the blues."[18] Baker emphasizes the words 'training' and 'trained' in order to express their status as double within the vernacular project that is the blues (vernacular understood here etymologically as the language of slaves, the verna, or of the vulgus, the common crowd). On the one hand, Baker means to relate this project to a specific, material location--the railroad crossing; on the other, he means to emphasize the virtuosity of the blues singer as specific signatory to his song. But the pun is meant as well to signal the critic's own implication in the "blues matrix"--he is a "trained critic."[19] This kind of word play--and the way it implicates the critic who engages with it--is characteristic not only of the blues but, seemingly, of artistic production in the vernacular in general. For example, the troubador lyrics which give birth to vernacular writing in Europe of the eleventh and twelfth centuries indulge in just the same kind of linguistic procedures. Guillaume Neuf, the first and already the most accomplished of troubadors, calls his poem a vers; but he also makes strategic use of the word as preposition, so that any poem, any vers, is also a 'towards', a vers, a writing towards some other person (and hence his use of the envoi).[20] If Guillaume styles himself a reliable or certain master ("Qu'ieu ai nom 'maistre certa"'), that mastery must be understood within the specific context of vernacular writing as a writing towards some other. [21]

Guillaume claims to be master of three things: poetry, games of chance, and love. A strange kind of mastery, then, that rather than asserting its selfsufficiency, bases itself upon a willingness to submit itself to an other: the poet, Guillaume asserts, does not know the meaning of his poem but awaits it as the response from a reader; the gamester submits himself to odds and risks; the lover's success depends, not upon his own proper pleasure, but upon his partner's. Hence, the vernacular writing of the troubadors, rather than being the oft-asserted pure and self-reflexive enacting of desire, is deeply social, insofar as it stakes its claims for efficacy upon its radical implication in the lives and judgments of other vernacular speakers. [22] This, in its most basic form, is what I call the social poetics of the vernacular. It was first elaborated and acted out by the troubadors, but it continued to exert a powerful force on all European, vernacular writers of the Middle Ages (Dante and Chaucer, for instance, are its direct heirs). 
My claim is not that vernacular writing and its social poetics form a tradition (whether this word is understood as a relation to time or to content) but that it must be construed as a situation, one that might be understood as a creation ex nihilo, of something that might be called social and only belatedly cultural. When Guillaume writes a poem "de dreyt nien," out of and about absolutely nothing, and when Thelonious Monk "play[s] things I've never heard before," something of the same situation is, I believe, at stake in both cases. Both men are interested in the creation of something absolutely new; and both ask, explicitly or implicitly, from where it comes and, more importantly, for whom it is destined and in what mode it will be recognized as such. The medieval poet and the modern jazz musician both compose works which are, first and foremost, challenges to the ones who read or hear them (just as both challenge themselves with the enigmatic nature of their own compositions and creations). The Poictevin poet and the African-American pianist share a common situation: both struggle to make a vernacular culture, which in principle does not yet exist, come to life. Before they are the recorders or compilers of an 'other' tradition (over and against a classical or romantic one), they are the creators of something absolutely new. Hence both must involve themselves in the creation of a social situation in which that creation can be received and responded to. The value of their creations cannot be determined as an an evaluation of taste or meaning or form; rather, their value is an effect of the works as experiments. That is, their condition is that of having "no assigned addressee" and no "regulating ideal" so that their value "is measured by the distortion that is inflicted upon the materials, the forms and the structures of sensibility and thought."[23] The rhythmic and semantic distortions of Guillaume's verse or the impossible production of quarter tones in Monk's compositions engage the receivers of their messages in something of the same experiment. It is not the shared assumptions or cultural contexts that yoke the sender of the message and its receiver together; rather, it is indeed the very absence of these criteria that forces sender and receiver alike to circulate around a common lack or default of meaning (what Chaucer calls, in Troilus and Criseyde, the "defaute of tonge").

Neither ground nor horizon, a lack or default of meaning should be finally unassimilable to the rhetoric or metaphysics of the 'absent cause'. If the vernacular does not contain its own meaning, that in no way implies that elsewhere (in the mind of God or in History) that meaning exists (as a repressed or cultural unconscious). The vernacular, then, experiences its own sociality as its own heteronomy--the inability of the social to name itself according to any external or transcendental nexus. It seeks its name in the other's response, its vers, and never in some beyond in which the two interlocutors are already summed up in advance. The vernacular names itself as the impossible problem of its own naming. "I am Arnaut, who hoards the wind,/ and chases the hare on an ox,/ and swims against the tide," as one of Arnaut Daniel's envois would have it.[24] 
What I am arguing then, is that what makes a vernacular poetics social is not a shared body of constitutive meanings in the vernacular--that is, not a discourse--but a lack of meaning out of which sociality arises and around which it circulates. My guiding principle, if it can be called one, is that vernacular productions cannot be read simply by being situated within an already established group of social facts, but that vernacular productions, more radically than is generally supposed, establish the fact of their own sociality. In this context, the social is not something given in advance but becomes the action (without rules but not without obligations--to hear, to respond, to write) of those beings who by virtue of that action will have been social.

What I am calling, therefore, the social poetics of the vernacular, might just as well name the adventure I have already called modernity, if we are now willing to hear in that word not a state of the world per se but the fact of the world as social transformation--the world acting itself out (for another) and hence transforming itself. Hence I have absolved myself from both dialectical and structural accounts of the social in favor of what I think must be called a postmodern account--the social as what it will have been.

The question remains, however, how it is that one is able to recognize, even after the fact, this thing that I have referred to as modernity? How does modernity name itself or sign itself? And can it name itself precisely as itself if, as I am suggesting, that is precisely what it does not or cannot know? How does the game played as modernity become the play of names in modernity?

The signatures of and to modernity will not have been, in essence, proper names. When all is said and done, they will take the form of metaphors, of pseudonyms arising from the very performance of their modernity. Guillaume Neuf, Marcabrun, Cercamon. Duke Ellington, Count Basie, the Prez. The Beatles, Rolling Stones, Gerry and the Pacemakers. Three sets of three: the early troubadors, three American jazz musicians, three bands associated with what came to be called the "British Invasion." What these names share in common is that they all bear witness to their own metaphorical, pseudonymous status. They mark and sign moments of striking originality which name themselves not as the origins but as the effects of that originality.

The name, Guillaume Neuf, perhaps signifies a real, historical person, William the Ninth; but it may also mean the new Guillaume, that is, the new beguiler (guiller, to trick), signifying at one and the same time its tricky status as proper name and its origin, not in a genealogy, but precisely in the trickery and novelty of its verses.[25] Marcabrun, the dark or obscure mark, names the troubador poet about whom we are told in his vida that he was a 
foundling. He himself finds his origin in his mother's name, Na Bruna or Marcabruna, undoing in a single stroke the protocols of patrilineal descent which traditionally underwrite biographical certainty. [26] His name, then, plays precisely with the possibility of using rhetorical colors to make and unmake the world: "Del plus torz fens/ sui ples e prens,/ de cent colors per mieills chauzir."[27] And like the other two, Cercamon's name, as his vida makes clear, derives from his own poetic narratives: he is cerquar mon, the world searcher or circler, the first part of whose name traces, circles and hollows out the circle of the world and the letter ' $\mathrm{o}$ ' of its representation $(\mathrm{m}$ $o-n$, world).[28]

Like their troubador forebears, the jazz musicians also draw their names from the sphere of their own practice. They are dukes, counts, presidents, earls, or bosses only insofar as they stake their claim to royalty from within the musical society they themselves create. And the phenomenon is even more striking since it takes place in a nation where royal titles are strictly forbidden by law. And they gain these titles neither through descent nor through usurpation: strictly speaking, we are not dealing here with pseudonyms but with autonyms, with a radical thesis (a thetic, autodesignation) that is musical and social as well as onomastic.

Finally, the rock-and-roll bands name themselves as precisely that: the Beatles are not bugs but quite literally those who beat; the Pacemakers refer themselves less to anatomy than to the time and rhythm they can create; the Rolling Stones are not the keepers of a proverbial wisdom but instead create a new wisdom and a new proverb out of the name of their music (the stones or rocks that roll). All of these names refer to a rhythm, to a beat or pace, to a time that they keep and that is in their keeping--the time of modernity.

From Marcabrun to Muddy Waters (two names which are and are not the same), the names of modernity arise precisely from the possibilities and obscurities of the vernacular. These names are rooted only in the rootlessness of the language whose rhythmic, semantic and anagrammatic potentialities they actualize. My language here is perhaps misleading, because I do not mean to suggest that vernacular poets or musicians simply make heard something already latent in the vernacular as such. In fact, the case is precisely the opposite. It is only insofar as the vernacular does not already contain within it the existence of its addressee that it makes possible its creation as someone or something absolutely new. This is why the vernacular cannot be assimilated to a discourse. It does not house within itself, as meaning, an already constituted destination or origin. And it is because it lacks precisely that meaning that it creates a new one at the end of, and in response to, its song. It experiments, takes its chances, rocks and rolls the dice. 
"Perkin's Wiggle" names one such experiment. The notes to the recording give the song's title as "Perkin's Wiggle" rather than "Perkins's Wiggle." That is, apparently, the proper name, Perkins, is declined in a heteroclite manner, the genitive case transforming the root, Perkins, to Perkin. This onomastic transformation strikes me as fortuitous, to say the least. The music of Carl Perkins might easily be described as 'perking' or percolating. Hence the wiggle does not belong, in strictu sensu, to the man, but to the name and its music (the name precisely as musical effect). The name calls attention to its own declension as a wiggling declension, literally heteroclite -- other-leaning or inflected towards the other. The song names its other, its addressee, as the possible transformation of its own and its author's name. The faulty or defaulted genitive marks the song not as a simple innovation but as an experiment in search of its destination, on the off-chance that it might find the other who might restore to it a meaning it never really had.

The problematical nature of my own experiment is now becoming clear to me. How to write the history of modernity? How to write the history of experiments that have, strictly speaking, no history? Now, this history can be written, I think; but it can only be written if one takes seriously and to the letter the claims of these texts to their own auto-origins, or what amounts to the same thing, their radical lack of origins. A history of originality without origin, then; a history not of social transformations but of the social as transformation, of 'changing tunes' (a phrase that is, finally, not descriptive but prescriptive, an address in search of its addressee, into whose keeping is entrusted the meaning of the name of the addresser). And that is why the history of modernity can only be written by those who are willing to take on this responsibility and this risk, those who are willing to respond to an address, even and especially when that address comes from a past that never ceases to name itself as the present--its own and ours.

\section{A Coda}

I began this essay by posing to myself the enigma of the Perkin's Wiggle. The song now strikes me as being something of a trobar clus, the name that the troubadors gave to their most hermetic verses, the 'closed text' that seduces one into believing that its secret can be pried loose from it--a secret "we don't understand," sings Carl Perkins, echoing across the ages the "no say de cuy" of Guillaume Neuf. And that, no doubt, is the point. One can only do the Perkin's Wiggle insofar as one does not understand it. Not a "genesis of secrecy" but a genesis from secrecy that is a genesis of sociality--of the possibility of an other.[29]

'The possibility of an other'--that, finally, is how I would like to phrase modernity and the vernacular. Every time I listen to "Perkin's Wiggle" I feel that I am possibly that other, other than myself as I wiggle along with the 
voice and guitar of Carl Perkins. When I put the song on the stereo I can do the wiggle by myself, or with a friend, or with my lover. The living room is suddenly transformed into a dance floor. It is only at that moment, when "Perkin's Wiggle" becomes my wiggle, or our wiggle, that it most fully becomes Carl Perkins's wiggle again. We transform the genitive case of the proper name, undo the property rights of solitary individuals. I make the wiggle yours; you make it mine. An other is possible--modernity. We don't understand.

After its recording in 1956, "Perkin's Wiggle" was not released as a record. It remained on tape and lived out its life in live performances alone. This simple fact points to both the precarious (but also living) status of vernacular composition and, I think, to one of the primary functions of cultural studies: to release vernacular composition from its thralldom to a modernity that defines itself as its own representational and discursive consolidation, even and especially when the spokespersons for that modernity march beneath the banner of a critical and supposedly liberating theory.[30] /pp37-38/

Hence the history of the "Perkin's Wiggle" must be the history of its own post-release, of what will not have been its modernity, but its post-modernity. If you want to hold the song near, or hold it dear, you can't hold it as a heritage or a legacy. You can't hold it at all; you can only hold someone else. My son, not yet two years old, can, I think, do the Perkin's Wiggle. And the other day, after the song and the wiggle were through, he paused and sang "Happy Birthday" to 'dear Carl Perkins'. He seemed to realize that the birth of 'pop' comes only after the song; he disclosed its secret through the 'just naming' of his own. And then we danced to "Blue Suede Shoes."

\section{Syracuse University}

Dept. of English

Syracuse - NY 13244 - USA

/p 38/

[*] This paper was originally delivered as part of a lecture series organized by Stephen Melville and Robyn Wiegman at Syracuse University. In general, I have refrained from making too many changes to the original text. 
[1] Carl Perkins, Original Sun Greatest Hits (Santa Monica: Rhino Records, 1986). Most people will associate "Blue Suede Shoes" with Elvis, who did an early cover of the tune and who was, as far as I know, the first one to perform it on television. Paul Willis reads the song as "a defiant stand on his [Elvis's] own cultural identity." See "The Golden Age," in Simon Frith and Andrew Goodwin, eds., On Record (New York: Pantheon Books, 1990), pp. 43-55. My own reading of the song, at least as performed by Perkins, is at odds with Willis's. It should be noted that Perkins did not know the phrase, 'don't step on my blue suede shoes', until his producer, Sam Phillips, suggested it as a title for a song. Phillips had heard it from Johnny Cash, another member of the Sun Studios gang, and who had heard it while in the army. Perkins repaid Cash, so to speak, by writing "Daddy Sang Bass," a tune Cash sang and which was number one on the country charts for six weeks. The song includes bits of "May the Circle be Unbroken," the Carter Family classic. Cash married into this bastion of the country music aristocracy. At the time (1968) Perkins was making his living playing guitar in Cash's stage band.

[2] Describing the Florentine plague of 1348, Boccaccio writes in the Introduction to the Decameron: "And this plague was of so great a force that it was communicated [communicare] to the healthy by contact with the sick, not unlike the way a fire close to dry and oily things will set them aflame." Throughout the Introduction, Boccaccio's emphasis is on the plague as communicable disease, as a social disease inherent within the social and transformative processes of language. The fire metaphor may perhaps derive from Dante, who, invoking the power of poetry, language and prayer in Canto I of the Paradiso, uses the following image: " Poca favilla gran fiamma seconda," a great flame follows a small spark. In the House of Fame, a poem greatly indebted to both Dante and Boccaccio, Chaucer picks up the image while describing the power of rumor: "As fire ys wont to quyke and goo/ From a spark spronge amys,/ Til alle a citee brent up ys." In making an equation between language and social conflagration in a poem about fame, Chaucer seems to have uncovered something of a wiggle in Dante's line, transforming it to: Poca favella gran fama seconda, great fame follows a small speech (or tongue). Chaucer sometimes writes of himself as possessed of a "litel tonge," and not without innuendo. It would be foolish to insist upon any direct connection between the metaphorics of medieval vernacular poetry, through tradition or influence, and early rock and roll. However, what I will insist upon is the commonality of metaphors between the two in order for them to describe the vexed status of vernacular creation.

Something like this connection was already hinted at, albeit in a vague and intuitive way, by Stephen Manning, "Game and Earnest in the Middle English and Provencal Love Lyrics," Comparative Literature, 18 (1966), 225-241. Manning draws an analogy between what he calls the "realism" one "experiences" in medieval, vernacular lyric and rock and roll.

[3] It is perhaps interesting to note that Perkins's music was produced at the time in which Dr. Benjamin Spock's Baby and Child Care was reaching its ascendency as the modern bible of childrearing. First published in 1945, it 
reappeared in an expanded and revised edition in 1957. In the section entitled "The Facts of Life," in which Spock advises parents on the ways in which to handle the sexual researches of young children (in general he counsels simplicity, matter-of-factness, and fidelity to scientific knowledge), he makes the following comment: "Actually, the question [of where babies come from] is more apt to be popped in the middle of the grocery store or while you are talking on the street...." Perhaps then, Perkins's use of 'pop' has the effect of maintaining the question of both social and sexual genesis as a question rather than an answer. Along the same lines, when I gave this essay as a talk, I was asked whether I was simply missing the fact that Perkins was using an historically determinant vernacular current among people of color at the time. When I explained that Perkins was white, and further that the term "race music," as used in the fifties, did not necessarily mean music made by African Americans, the questioner looked confused. And that is the point. I would concede, however, that what I am arguing about the vernacular has something to do with class, but only if class is understood not as a site of meaning but of a socially transformative action not staked upon meaning but effective and real nevertheless.

[4] The dictum is Fredric Jameson's. See The Political Unconscious (Ithaca: Cornell University Press, 1981), p. 9. My quarrel with Jameson is in a sense a very simple one. For him, in this book at least, history is the necessary and "inexorable form of events" (p. 102). These events have their "ground and untranscendable horizon" in the "absent cause" that is History itself. This notion is both Marxian (Althusser) and theological (Spinoza). The "absent cause" is something substantive; it has a meaning (which, no doubt, will be revealed at history's end) and produces out of itself nothing short of the destiny and "Necessity" of the world: "we may be sure that [History's] alienating necessities will not forget us, however much we might prefer to ignore them" (p. 102). It is this entire metaphysics that therefore enables Jameson's phrasing of the "absent cause" as the repressed, as a political unconscious, what Lyotard calls the "Great Zero" of representation (see Bill Readings, Introducing Lyotard (London: Routledge, 1991), p. 96). My aim in this essay is to think historically without the benefits and consolations of this metaphysics. When I speak of lack, loss or absence, I have in mind not some repressed content or meaning but a very real incapacity, for example, the simple inability of someone to say, exactly, what he or she means. This lackof-meaning is only a "cause" insofar as the one who experiences it hopes to find its redress in the words or actions of some other. This other, however, does not have it, so to speak, either. Hence, the community or sociality of these two is not 'caused' by a lack or absence, but constitutes itself as the circulation of lack (rather than the circulation of meaning or discourse). It strikes me that this is nothing else than Lacan's definition of love; and it is hardly an accident that the songs and poems encountered in this essay are all, in general, love songs or love poems. It is also no accident that medieval vernacular poets, for example, prescribed love as the true subject of vernacular poetry. It is in this sense that love is never simply an ideology, a discourse or a matrix of social and historical meanings. 
[5] Jean-François Lyotard and Jean-Loup Thébaud, Just Gaming (Minneapolis: University of Minnesota Press, 1985).

[6] In the Introduction to Bill Readings and Bennet Schaber, eds., Postmodernism Across the Ages (Syracuse: Syracuse University Press, forthcoming), we attempt to connect the temporality of the postmodern experiment with Freud's Nachträglichkeit or 'deferred action', the 'what will have been'. I do not believe this argument is incorrect; however, the present essay attempts to work through this problematic at the level and with the phrases these experiments have chosen as their own.

[7] Cf. M. Gatien-Arnoult, ed., Las Leys d'Amors (Genève: Slatkine Reprints, 1977), p. 8: "Alqus trobars ve per aventura, et alqus per bona cura." [There are two ways of finding (of making a trobar), by chance or through hard work.] The rhyme, aventura-cura, is a common one, especially in Chaucer.

[8] Richard Ellmann, James Joyce (New York, 1959), p. 535. Jefferson Airplane's third album, After Bathing at Baxter's, released late in 1967 by RCA Records, contains a nifty little number about Ulysses, "rejoyce," composed and sung by Grace Slick. Not accidentally, I think, it is the most 'classical' cut on the record, at least in its use of classical instrumentation (piano, oboe, flute) and what amounts to a contemporary (1967) jazz arrangement. It is also not accidental that psychedelia (of which the record is a prime and important example) made its home in and around universities. The album is worth a listen, especially now that psychedelia is staging a comeback in both England and America. Unlike the vernacular productions with which the present essay is concerned, psychedelia, strictly speaking, does have a history and experiences itself precisely as the possibility of a new or post-history. Hence its 'try it, I did', 'open the door, that's what it's for', and 'let's get up and get out' injunctions, as well as its fondness for anthems. One might also note psychedelia's especial fondness for modern technology and its representations--airplanes, starships, elevators, sci. fi., William Burroughs, flourescent paint--as well as for 'produced' drugs like LSD. These no doubt make up, at least in part, the technological means for procuring its utopian flights as well as helping to produce a discourse commensurate with its intended audience. This is not a recrimination; psychedelia's utopian visions have never seemed unattractive, at least to me.

Surface Page d'Acceuil/Home Page

[9] See, for instance, "An Encounter," in Dubliners. 
[10] The argument is Lyotard's.

[11] Richard Ellman, Ulysses on the Liffey (London: Faber and Faber, 1972), pp. xvi-xvii.

[12] Lyotard and Thébaud, p. 12.

[13] Ibid., p. 16: "JFL believes that he can dissipate today (October 1979) some of the confusion that prevails in this conversation on modernity by introducing a distinction between the modern and the postmodern within that which is confused here under the first term. The modern addressee would be the "people," an idea whose referent oscillates between the romantics' Volk and the fin-de-siecle bourgoisie. [...] Postmodern (or pagan) would be the condition of the literatures and arts that have no assigned addressee and no regulating ideal, yet in which value is regularly measured on the stick of experimentation."

[14] The songs are taken, respectively, from the following recordings: Thelonious Monk, Straight No Chaser (CBS Records, 1989); The Compositions of Duke Ellington, vol. 1 (Riverside Jazz Master Composers Series, no date); Miles Davis, Compact Jazz (Philips, 1989); Ella and Louis Again (Verve Records, 1957).

[15] The following are the lyrics to the first verse and chorus:

"They all laughed at Christopher Columbus, when he said the world was round;/ They all laughed when Edison recorded sound./ They all laughed at Wilbur and his brother, when they said that man could fly;/ They told Marconi, the wireless was a phony, it's the same old cry./ They laughed at me wanting you, said I was reaching for the moon,/ But oh, you came through,/ Now they'll have to change their tune./ They all said we never could be happy, they laughed at

us and how; But oh wo wo, who's got the last laugh now!" The song was originally written for the Astaire and Rogers film, Shall We Dance (1937). In the context of the film, my reading of the song would invariably be altered if not completely reversed. In Shall We Dance, modernity (and all of its mechanical apparatuses) gives itself as the absolute precondition of any sexual relation (which is stylized in such a way that it is never out of step with its Deco backdrop; and this seems to be precisely the conviction it seeks to produce in its audience: to be in step, to dance in time with contemporary, technological production, guarantees that one will be in step with, and finally dance with, the other sex). The Armstrong/Fitzgerald version produces just the opposite result.

[16] My 'reading' of "They All Laughed" opens up a question, the answer to which would go far beyond the scope of the present essay. That is, how are we to understand gender difference as the absolute and unmasterable precondition for what is being discussed here under the twin headings of modernity and the vernacular? I would simply assert, while saving the argument for another occasion, that gender forms the unmasterable and non-meaningful fact presumed by all vernacular and hence modern 
practices. Sexual difference is, indeed, the ultimate non-site of what I have called a lack-of-meaning. In dividing the social (and the subject, if we are willing to wager this rather vexed term) against itself, it is also its very possibility. Indeed, my argument suggests to me that gender traverses and fissures the entire field of voice-hearing-music, etc., perhaps in advance of its social registrations. The social organization of music, then, must account for, organize and manage precisely what it must presuppose in order that there be something like the social in the first place. Vernacular, modern practices, therefore, might be said to be recognizable precisely insofar as they refuse or are unable to give meaning to the sexual relation. In this sense, where I have used the word 'lack', I might also have used the word 'difference' in its most absolute sense. I think I would be prepared to argue that what a vernacular performance 'does not know' is that it knows that "there is no sexual relation," as Lacan would have it. Nevertheless, although I think vernacular practices, by their very nature, are not patriarchal or patrilineal, they are not by virtue of that, feminist.

[17] Stuart Isacoff, Thelonious Monk (New York: Consolidated Music Publishers, 1978), p. 6.

[18] Houston A. Baker, Jr., Blues, Ideology, and Afro-American Literature (Chicago: U of Chicago Press, 1984), p.8. I take leave of Baker precisely on the issue of "amelioration," since my phrasing of the vernacular suggests less that than a fresh start, so to speak.

[19] Ibid., p. 10.

[20] A fairly extensive sampling of troubador poetry, along with translations, can be found in Frederick Goldin, Lyrics of the Troubadors and Trouveres (Gloucester: Peter Smith, 1983). The envoi to "Farai un vers de dreyt nien" [I will make a vers out of (or: about) exactly nothing] is as follows: Fag ai lo vers, no say de cuy;/ e trametrai lo a selhuy/ que lo.m trametra per autruy/ lay vers Anjau,/ que.m tramezes del sieu estuy/ la contraclau. [I have made this vers, I don't know what it's about; and I shall send it to someone who will send it for me with someone else there towards Anjou; let him send me from his little box the key to this riddle.] In his poem Guillaume claims not to know whether he sleeps or wakes "if someone doesn't tell me," s'om no m'o ditz; he claims to be sick and trembles at the prospect of death, but again, he doesn't know it "except when I'm told," e ren no sai mas quan n'aug dir.

[21] This vers begins: "Ben vuelh que sapchon li pluzor/ d'est vers si's de bona color,/ qu'ieu ai trag de mon obrador." [I want everyone to tell me whether this vers is of good color that I have brought forth from my workshop.] Once again, the poem goes in search of a response. Unlike the previous poem, Guillaume claims to know ("Ieu conosc") a great many things; but after listing his accomplishments as poet, gambler and lover (he claims he could earn his living as the latter), he tells the story of a game of love, juec d'amor, in which he is, at first, the loser: "quan guardiey, no m'ac plus mestier,/ si.m fon camjatz." [I took one look, and I no longer had the craft (or: I was no longer the master), I was that unnerved.] His partner reproaches him, elha.m dis un reprovier, since quite obviously, in this game at least, when one loses, so does the other. They play a second time with 
great success (there is a dicing conceit throughout). What is at stake here, then, is the other's desire and pleasure as the precondition of one's own. That is the meaning--purely pragmatic since linked to singular cases--of mastery.

[22] Cf. R. Howard Bloch, Etymologies and Genealogies (Chicago: University of Chicago Press, 1983): "From the beginning the vers represents a symbolic closure of language upon itself, its substitution for action and its constitution as event" (p. 114).

[23] Lyotard and Thébaud, p. 16.

[24] "Ieu sui Arnautz q'amas l'aura,/ e chatz la lebre ab lo bou/ e nadi contra suberna." In his Medieval Theories of Authorship (London: Scolar Press, 1984), A. J. Minnis argues persuasively that a rigorous theory of authorship did in fact exist. However, as his research makes clear, that theory was elaborated exclusively within the sphere of Latinity. The vernacular writer, then, was left in the lurch, so to speak, since he or she could not name the exact status or meaning of his or her authorship without risking the becoming Latin of the vernacular text (and hence falsifying it). In this context, rather than speaking of lack or absence as the condition both of vernacular writing and vernacular sociality, it might be better to speak of "retraction" or even censorship. That is, if the vernacular has no stable vocabulary or terminology through which it can say exactly what it means or who its author might be, it might be said to retract itself at the moment it risks becoming another, meta-discursive language (Latin, for instance). Censorship, in this case, would imply the self-censoring procedure of the vernacular text in the face of a dominant language which inevitably and violently would go further: to censor the very specificity of the vernacular in favor of a universal grammar, orthography and meaning (which Latin always claims as its own). This leads to the enormous problem of just what exactly constituted vernacular literacy in the Middle Ages (not to mention what constitutes it in our own day). See Brian Stock, The Implications of Literacy (Princeton: Princeton University Press, 1983).

[25] Roger Dragonetti, Le gai savoir dans la rhétorique courtoise (Paris: Seuil, 1982), pp. 33ff.

[26] Ibid., pp. 26ff.

[27] "I'm chock full of the nastiest tricks, with a hundred [rhetorical] colors from which to choose the best."

[28] For Cercamon's vida, see George Wolf and Roy Rosenstein, eds., The Poetry of Cercamon and Jaufre Rudel (New York: Garland Publishing, 1983), p. 4.

[29] I am not implying that the 'secret' of vernacular texts involves its practitioners in something like religious mysteries or in a cult of election. Hence the distance I take from the problems of interpretation involved in reading texts that do engage in this kind of mystical secrecy. See Frank Kermode, The Genesis of Secrecy (Cambridge: Harvard University Press, 1979). 
[30] What is being called to account here is the long-standing and continually vexed question of critical engagement. Contemporary criticism continues to live out the debate joined in 1953 when Barthes published Writing Degree Zero as a response to Sartre's What is Literature? over the meaning of "engagement." The argument has not gone away, even if it has shifted its ground from

engaged literature to engaged criticism. Cultural Studies (or cultural critique) has, in a sense, placed its wager on the side of Sartre (and

frequently with good reason and to good effect). What I am questioning, however, is whether its insistent invocation of History might have the effect of settling its objects in a rather anemic past (or present) rather than granting them to power to work upon and unsettle the present. On the other hand, one must acknowledge the immense flexibility and scope of Cultural Studies. My own aim, here, has been first to treat music, at least in a provisional way, as figurative or figural (Lyotard's word) in advance of its discursivity.

What I have not been able to do in this essay is really push toward an argument about the sonic opacity (this kind of catachresis is inevitable, I think, and needs to be accounted for) of music qua

figure. Simon Frith and Andrew Goodwin, eds., On Record (New York: Pantheon Books, 1990), is the best record, so to speak, of the engagement of Cultural Studies with popular music over the last fifty years. 